\title{
An appraisal of prodigal loss of vigour and viability of bamboo seeds
}

\begin{abstract}
Seeds in general play a vital role in man's life since they serve as a source of food, fibre, spices, beverages, oils and drugs. Seeds of cereals contribute about $90 \%$ of all the cultivated plants, as the source of up to half of global per capita energy. Bamboo seeds have very short viability of 1-3 months and are therefore useful as propagates for only a short period of time. Seed deterioration is inevitable and the best that can be done is to control its rate. Seed ageing is affected by a number of factors during seed storage. However, there is very little information on the physiology and biochemistry of seed viability with ageing of bamboo seeds. The speed at which the seed ageing process undergoes depends on the seeds' ability to counter attack the break down changes as well as on species-specific protection mechanisms. In seed ageing, damage to cellular membranes, decrease in sugar, lipid, amino acid, proteins and hormonal contents' activities. Aged seeds show decreased vigour and produce weak seedlings that are unable to survive. Sometimes, non-availability of quality seed is also one of the major snag in enhancing the productivity.
\end{abstract}

Keywords: seed, ageing, storage, vigour, biochemical changes
Volume 8 Issue 4 - 2018

\author{
Vikas Kumar,' Richa Puri² \\ 'Assistant Professor of Botany,Wrs Government Post Graduate \\ College, India \\ ${ }^{2}$ Richa Puri, Professor, Department Of Botany, Panjab University, \\ India
}

Correspondence: Vikas Kumar,Assistant Professor of Botany, wrs Government Post Graduate College, Dehri, Kangra, Himachal Pradesh, I76022, India, Tel +9I-94I8083357, EmailVk.Guleria@Gmail.Com

Received: February 23, 2017| Published: July II, 2018

\section{Introduction}

The present review was undertaken with an aim to appraise the physiological and biochemical factors (i.e. metabolites, enzymes, membrane integrity and levels of growth hormones) that lead to loss of seed viability during storage. The knowledge so generated would be helpful in devising techniques for enhancement of vigour and viability of ageing bamboo seeds. Because, most of the bamboos flower at long intervals of 7-20 years. Bamboos comprise the most diverse group of plants in the grass family. They are distinguished from other members of the family by having woody culms, complex branching, a complex and generally robust rhizome system, and infrequent flowering. Bamboos are plants of global interest because of their distinctive life form, ecological importance and the wide range of uses and values they have for humans. ${ }^{1}$ They have been variously called as 'The Cradle to Coffin Plant', 'The Poor man's Timber', 'Friend of the People', 'Green Gasoline', 'The Plant with Thousand Faces' and 'The Green Gold'. There are more than 1500 different documented traditional uses of bamboo. ${ }^{2}$ The seeds in bamboos are therefore scarcely available. This cyclic flowering in bamboos is gregarious and produces huge quantities of viable seeds. Bamboo seeds have very short viability of 1-3 months and are therefore useful as propagules for only a short period of time. Several studies on tropical bamboo seeds have reported prompt and high germination rates upon hydration (often around $80 \%$ ) and/or marked declines in seed viability within a matter of 1-2 months. ${ }^{3-7}$

\section{Seed viability and longevity}

Seeds, like any other plant organ, age with time and consequently die. However, the rate at which seeds age depends upon their physiological status, their genetic constitution, and the storage conditions. The availability of an adequate supply of seeds of a uniform high quality is essential for a successful seed industry and the maintenance of a viable and productive agriculture ${ }^{8,9}$ Recognized two types of seeds on the basis of their storage behavior viz., orthodox and recalcitrant. More recently, a third category (still undefined), intermediate between the orthodox and recalcitrant categories, has also been identified. ${ }^{10}$ Orthodox seeds are characterized by their ability to tolerate desiccation and to retain their viability for a long time in the dry state. However, these seeds age during storage and eventually lose their ability to germinate. Lipid peroxidation and the loss of membrane phospholipids are major causes of seed ageing under natural ageing conditions $^{11,12}$ several studies of long-term storage detected little or no lipid peroxidation and loss of phospholipids from seeds of rice ${ }^{13}$ soybean, ${ }^{14}$ and wheat. ${ }^{15}$ Under the long-term storage conditions, seeds are likely to be in the glassy state (A glass is an amorphous, nonequilibrium solid and is characterized by its extremely high viscosity. High levels of sugars and other biopolymers in seeds result in a rapid increase in cytoplasmic viscosity during drying, which prevents the cellular biological system from reaching physical and chemical equilibrium in a measurable time frame ${ }^{16}$ because of the cool storage environment and low seed water content. The extremely high viscosity and low molecular mobility of the seed cytoplasm could prevent or inhibit many deleterious processes. ${ }^{17-20}$

\section{Physiology of seed germination}

The seed is a propagated by which a seed-bearing plant is dispersed and propagated. ${ }^{21}$ The seed also provides protection and nutrition for the quiescent $t^{22,23}$ described seed as a critical phase in the life of plants, as the time, place, and nutrient reserves available upon germination mainly determine the successful establishment of plant. According to ${ }^{24}$ germination is traditionally divided into three basic phases:

a) Imbibition, the absorption of water needed for hydration of proteins and cell organelles, as well as a substrate for hydrolytic reactions.

b) Activation of metabolism, involving synthesis of nucleic acids and proteins, increase in enzyme and respiratory activities and initial reserve breakdown (this step was called "germination sensustricto" by. ${ }^{25}$

c) Visible growth, usually in the form of root protrusion. ${ }^{21}$ 
Mobilization of reserves during germination is a catabolic process in which the reserve food material is broken down with the help of enzymes and utilized for repair and growth mechanisms by the seed..$^{21,26,27}$ Following imbibition and under the control of signals, particularly GA (Gibberellic acid) from the embryo and scutellum, the cells of aleurone layer synthesize an array of hydrolytic enzymes that are transported into the endosperm. These hydrolytic enzymes include $\alpha$-amylase, $\beta$-amylase and de-branching enzymes. $\alpha$-amylase is synthesized de novo, ${ }^{28}$ probably from amino acids released by proteolysis of storage proteins in the aleurone grains. This enzyme cleaves the internal $\alpha-1,4$-linked bonds of the glycan chains, releasing shorter amylose chains that are then further hydrolyzed to maltose (a disaccharide) by $\alpha$-amylase. On the other hand, in dicots, the degradation of starch yields glucose and maltotriose. ${ }^{29}$ The majority of $\beta$-amylase is already present in the endosperm in an inactive form in the quiescent grains, but later during germination it is converted into active state by GA induced proteinases from aleurone layer. It cannot hydrolyze native starch grains until they are broken down into large dextrins by $\alpha$-amylolytic attack. Nandi et al. ${ }^{30}$ reported that long-lived $\beta$-amylase plays an important role in starch degradation and helps in initiating early embryo growth. Both $\alpha$ and $\beta$-amylase are unable to hydrolyse $\alpha-1,6$ bonds in the branch points in amylo pectin. Specific, de-branching enzymes are required to hydrolyze these bonds and release additional amylose chains for further degradation. The $\alpha$-glucosidase, limit dextrinase and cell wall hydrolases are synthesized by the aleurone layer and transported along with $\alpha$-amylase into the starchy endosperm. In some seeds, the major carbohydrate reserves are in the form of cell wall galacto-mannans and the corresponding hydrolytic enzymes are endo- $\beta$-mannanase, $\beta$-mannosidase and $\alpha$-galactosidase. ${ }^{31-34}$ In cereals, the protein reserves are stored in two separate sites viz. in the aleurone grains of aleurone layer (about 20\%) and in the protein bodies of the endosperm (about 70\%). Hydrolysis of storage proteins into amino acids or smaller peptides is carried out by proteinases/proteases. ${ }^{35}$ The free amino acids released are utilized for protein synthesis or transported to the growing axis. Protein degradation in seed storage tissues during germination does not occur at once in the entire organ. The region where degradation starts varies from species to species. ${ }^{36-37}$

\section{Effect of storage on seed viability}

The fact that seeds of most species can be dried and stored from year-to-year has been exploited by man since the beginning of agriculture. Indeed, the ability of many orthodox seeds to remain viable for tens or hundreds of years in dry storage, ${ }^{38}$ indicates that they can be used for the long-term ex situ conservation of plant germplasm. Though the causes of deterioration of seed viability during storage has not been fully understood, scientists relate it to bioenergetics disturbance, ${ }^{39}$ damage to nucleic acids, ${ }^{40}$ loss of vitamins and hormones ${ }^{41-43}$ and membrane deterioration. ${ }^{11,42,43}$ Several comprehensive reports have shown that loss of seed vigour and viability is associated with free radical-mediated lipid peroxidation, enzyme inactivation or protein degradation, disruption of cellular membranes, Maillard reactions and oxidative damage to genetic (nucleic acids) integrity. ${ }^{12,44-46}$ A number of studies have reported potential correlation of seed longevity in dry storage with seed mass, oil content, carbohydrate composition and climate. ${ }^{38,42,47}$ However, a purported link between high oil content and short storage life-span has not been supported by recent analyses. ${ }^{4,38}$ showed that reducing the moisture content of Dendrocalamusstrictus seeds to $8.4 \%$ and storing them in wax paper bags helped maintain seed viability. Rapid loss in viability of seeds occurred within 5-months under ambient conditions $\left(25-34^{\circ} \mathrm{C}\right)$ whereas under vacuum $\left(\mathrm{CaCl}_{2}\right.$ in a desiccator at $\left.25-34^{\circ} \mathrm{C}\right)$ or cold storage $\left(10^{\circ} \mathrm{C}\right)$ conditions the deterioration was gradual. Seeds stored at low temperature i.e. 0 to $5^{\circ} \mathrm{C}$ showed highest viability percentage after 9 -months. Seethalakshmi ${ }^{48}$ suggested two methods for the storage of bamboo seeds viz. cold storage and storing seeds over desiccants like calcium chloride at room temperature and the later was reported to be most effective. Warrier et al., ${ }^{49}$ studied that storage of wet seeds of Bambusaarundinacea also poses problems. Desiccator drying of seeds was found to retain viability while sun drying proved detrimental. Moisture content of seeds could be reduced to as low as $1.90 \%$ for effective storage.

\section{Membrane integrity and seed ageing}

Biological membranes with a normal composition and organization regulate the transport of materials into and out of the cell. Therefore, they play a key role in maintaining seed viability and vigour. Solute leakage accompanies seed imbibition during the process of membrane reorganization following rehydration. The rate of leakage depends on the degree of cell membrane damage and repair in response to ageing may constitute an important factor in explaining seed deterioration. ${ }^{50-52}$ In seed ageing, damage to cellular membranes, decrease in mitochondrial dehydrogenases activities, chromosomal aberration and DNA degradation increases.$^{53}$ Electrical conductivity measurements of seed leachates are routinely used to determine seed vigour in a number of species. ${ }^{54-55}$ Ion leakage (e.g., $\mathrm{K}^{+}, \mathrm{Mg}^{2+}$, $\mathrm{Cl}^{-}, \mathrm{Ca}^{2+}$, and $\mathrm{Mn}^{2+}$ ) has been shown to relate to seed viability and vigour. ${ }^{56,57}$ Leakage of sugars is considered a less reliable index of membrane integrity than the leakage of electrolytes. ${ }^{58}$ It is also not clear if sugar leakage from the embryo and endosperm are equally important for seed vigour.

\section{Metabolic changes during seed ageing}

Seed ageing is a natural phenomenon which occurs in all seeds, even if they are stored in dry and low temperature rooms. ${ }^{59}$ The main factors affecting seed ageing are the temperature and relative humidity at which the seeds are stored, the moisture content of the seeds and the seed quality. Generally, high moisture levels and temperature reduce seed longevity and cause profound deteriorative biochemical changes in seed membrane, DNA and food reserves. ${ }^{12,45,46}$ Time and again researchers have correlated seed ageing with biochemical changes such as alteration in protein synthesis ${ }^{60}$ degradation of DNA and RNA (Wilson and McDonald, 1986); degradation of hydrogen peroxide detoxification pathway; ${ }^{61}$ deterioration in membrane properties. ${ }^{53,62}$

\section{Effect of ageing on enzyme activity}

Seed deterioration has been associated with chromosome aberrations and changes in RNA synthesis, in proteins and then enzymes. Incomplete protein synthesis occurs due to DNA degradation that impairs the transcription and translation process. ${ }^{12}$ There have been reports of differential respiratory and enzymatic activity with ATP production and membrane alterations. A scrutiny of literature suggests that cellular and physiological aberrations are a main cause of loss of viability during seed ageing. Smith and Berjak ${ }^{45}$ showed that with ageing the membrane of the seed become leaky, enzymes lose catalytic activity and chromosomes accumulate mutations. VanBilsen et al., ${ }^{44}$ also reported that membranes become more susceptible to imbibition damage with ageing. Commonly, seed deterioration is reported to accompany changes in enzyme activity during ageing. ${ }^{43,63-65}$ Although 
seed deterioration is generally accompanied by loss of enzyme activity, ${ }^{9}$ a few hydrolytic enzymes like $\alpha$-amylase and proteases show an increase in their activity. ${ }^{66}$ Several workers have shown a decrease in amylase activity with ageing. Saxena et al., ${ }^{43,64-68}$ reported that enzymes catalase, peroxidase and total dehydrogenase showed a decline in activity in aged seeds of sesame (Sesamumindicum) subjected to accelerated ageing at $45^{\circ} \mathrm{C}$ and $10 \% \mathrm{RH}$, while invertase, RNA-ase and acid phosphatase showed an increase in their activity with ageing. However, with further increase in age, these enzymes showed a decrease in their activities. Kannababu \& Karivaratharaju ${ }^{69}$ reported that accelerated ageing of sunflower seeds showed a decrease in activity of malate dehydrogenase and succinate dehydrogenase in both cotyledons and embryonic axis of germinating seedlings of sunflower (Helianthus annuus).

\section{Effect of ageing on antioxidant system of seeds}

The ascorbic acid (ASC) system functions dynamically in seeds, although the strategies for ASC production and utilization may vary according to seed developmental and functional stages. ASC has been considered almost uniquely for its antioxidant properties, ${ }^{70,71}$ since ASC can react with reactive oxygen species (ROS) such as hydrogen peroxide, superoxide radical and hydroxyl radicals in nonenzymatic reactions. It is now clear that ASC also has a paramount role in both animal and plant cells as a co-substrate necessary for the activity of many 2-oxoacid-dependent dioxygenases; $;{ }^{72-75}$ Plant systems resist toxic oxygen species based on the presence of reduced molecules such as glutathione, ascorbate, enzymes such as superoxide dismutase (SOD), catalase, glutathione reductase (GR) and ascorbate peroxidase (APX). Thiols are first affected by oxidation due to the presence of sulfhydryl groups. Reduced glutathione (GSH) is a major non-protein thiol that plays an important role in storage, transport and maintenance of the redox status in cells $;{ }^{70,71} ;$ Klapheck et al. ${ }^{76}$ reported the role of GSH in germinating castor beans during oxidative stress as it degraded $\mathrm{H}_{2} \mathrm{O}_{2}$. Early products of radical-mediated reactions in vitro can be detected by electron paramagnetic resonance (EPR) studies. Less direct evidence comes from measurement of specific activities of enzymes such as SOD, GR, APX, etc. EPR studies of high and low vigour dry embryos of rice seeds stored in a warm and humid environment were tested for the presence of free radicals by Nandi et al. ${ }^{30}$ The results indicated that high vigourunaged embryos possessed high activity for the antioxidant enzymes, SOD and POX. It was observed that the balance between free radical/oxidative chain products and the integrity of active oxygen-scavenging enzymes present in dry embryos determined the fate of membranes and macromolecules during imbibition and early germination. Since ASC is known as an antioxidant and APX is known to catalyse the removal of hydrogen peroxide, much attention has been given to their possible involvement in the mechanism of seed defence against oxidative stress occurring during desiccation. ${ }^{77}$ However, this is not consistent with the fact that both ASC and APX activity decrease during the desiccation stage. ${ }^{77,78} \mathrm{APX}$ protein content in barley is associated with early grain filling and then typically decreases during desiccation. ${ }^{79}$

\section{Effect of ageing on seed membrane phospholipids}

A perusal of the literature suggests that there may be several mechanisms of seed ageing. ${ }^{71,80,81}$ Although lipid peroxidation and the loss of membrane phospholipids are regarded as major causes of seed ageing, ${ }^{8,12}$ yet several studies of long-term storage detected little or no lipid peroxidation and loss of phospholipids from seeds of soybean, ${ }^{14}$ and wheat. ${ }^{15}$ Although the longevity of seeds is enhanced by storage under dry conditions, eventually the seeds deteriorate and lose the ability to germinate. One of the most commonly cited hypotheses explaining seed deterioration points to lipid peroxidation as the mechanism by which cellular membranes are disrupted. ${ }^{8,14,52,82}$ There are many types of peroxidative reactions in which lipids serve as substrates, but the most commonly accepted view involve breakage of the ester linkage between the acyl chain and the glycerol backbone ${ }^{82}$ or attack of unsaturated bonds of the fatty acid chain. ${ }^{83}$ Both triglycerides and polar lipids are subject to these reactions, and if these reactions occurred, the chemistry of the lipid components of the seeds would change. Unfortunately, studies on the changes in lipid chemistry with seed deterioration have produced mixed results, ${ }^{52,82}$ and a consensus regarding the importance of lipid peroxidation in seed deterioration has not been reached. Cellular membranes have been proposed as some of the primary sites of injury during desiccation and storage of seeds. ${ }^{12,62,84}$ This is mediated by an oxidative attack which promotes phospholipid degradation and loss of membrane organization..$^{85}$ It is unlikely that changes observed in the triglycerides are responsible for changes in seed viability; yet, it is possible that membrane lipids are susceptible to the same reactions. It has been suggested that changes in membrane lipids are involved in the loss of viability of stored seeds ${ }^{52,65,86,87}$ but measurements of the changes in the properties of membranes in vivo have not been possible using this technique. The mechanism by which the physical properties of storage lipids change is unknown.

\section{Effect of ageing on seed membrane proteins}

Ultra structural studies on seeds have distinguished between dry and imbibed seed tissues of soybean. ${ }^{88}$ studied characteristics of the organelles and cells under stress of chilling injury in soybean used electron microscopic (EM) studies. ${ }^{89}$ Most studies have focused on storage tissues such as cotyledons in soybean. ${ }^{89}$ Studies by Yaklich et al., ${ }^{90}$ on soybean seed anatomy using transmission electron microscopy (TEM) featured test a and the phloem and xylem of the vascular sutures in the soybean pod. It has been observed that protein oxidation can cause modification of amino acid side chains, backbone fragmentation, protein demonization or aggregation, and the unfolding or altered conformation of proteins. ${ }^{91}$ These structural changes alter the functional activities of the modified proteins such as their ability to modulate gene expression, cell signalling, apoptosis, and necrosis. Reactive intermediates from protein peroxides can induce chain reactions that cause damage to other intracellular targets such as DNA, lipids, and other proteins. ${ }^{12}$ Protein modifications are often associated with ageing and diseases. ${ }^{92}$ However, protein oxidation may provide a means by which reactive oxygen species are utilized or counteracted e.g. the restoration of metabolic activities following imbibition of mature dry seeds..$^{87,93-95}$ A major cause of deterioration in these seeds is the process that could contribute to the 'cascade' of changes associated with the execution phase of cell death. ${ }^{64,65,95}$

\section{Effect of ageing on changes in endogenous growth hormones}

Plant hormones and growth regulators are the chemicals that affect flowering; ageing; root growth; distortion and killing of leaves, stems, and other parts; prevention or promotion of stem elongation; colour enhancement of fruit; prevention of leafing and/or leaf fall; and many other conditions. Even small quantities of these substances produce major growth changes. Growth regulators are known to modify the growth and development pattern of plants by exerting profound effect on various physiological processes and hence regulating the productivity. ${ }^{96-100}$ suggested that $\mathrm{GA}_{1}$ and $\mathrm{GA}_{3}$ are the major 
gibberellins produced by the germinating embryo though $\mathrm{GA}_{4}$ and $\mathrm{GA}_{7}$ were also detected. Further it was suggested that $\mathrm{GA}_{3}$ and $\mathrm{GA}_{7}$ activate the aleurone cells where as $\mathrm{GA}_{1}$ and $\mathrm{GA}_{4}$ control the embryo growth. Other effective gibberellins are $\mathrm{GA}_{2}$ and $\mathrm{GA}_{22}$ while some such as $\mathrm{GA}_{12}, \mathrm{GA}_{17}$, and $\mathrm{GA}_{26}$ did not have any promotive action. A major role of endogenous GAs in the control of seed germination has also been emphasized by Karssen et al. ${ }^{101}$ Although it is well established that gibberellins (GAs) and abscisic acid (ABA) regulate amylase synthesis in the cereal aleurone layer, very little is known as to how GA and ABA affect amylase synthesis and secretion by the scutellum. ${ }^{102}$

Studies on the expression of $\alpha$-amylase genes in barley and rice scutella. ${ }^{99,103}$ However, indicate that the mechanism of their regulation is similar to that for the corresponding genes in aleurone layers. Along with regulating the synthesis of secreted hydrolases, ABA and GA influence other functions of aleurone layers and scuttle that relate to germination. The aleurone layer is the principal store of mineral elements in the grain of small cereals where $\mathrm{K}^{+}, \mathrm{Mg}^{2+}$ and $\mathrm{Ca}^{2+}$ are stored in the vacuole as chelates of phytic acid. ${ }^{104} \mathrm{GA}$ stimulates the synthesis of Phytase, and Phytase break down makes cations and phosphate available to the embryo. The viability of the cereal aleurone layer is also tightly regulated by ABA and GA. Haberlandt ${ }^{105}$ was among the first to report that cells of the aleurone layer die after reserves in the endosperm have been mobilized. ${ }^{106} \mathrm{ABA}$ promotes aleurone cell viability and GA promotes aleurone cell death. ${ }^{107,108}$ identified and quantified endogenous free ABA, IAA and GAs in the whole white spruce (Piceaglauca) seeds. It was reported that ABA content was high at the early stage of embryo development. Levels of IAA declined in the mega-gametophytes after pollination and through the seed development. Levels of $\mathrm{GA}_{4}$ slightly decreased while $\mathrm{GA}_{9}$ increased during this period. Kojima ${ }^{109}$ determined the endogenous level of IAA and ABA in tomato (Lycopersicon esculentum).

It was found that the concentration of IAA was higher in the symplast (SP) solution than in the apoplasts (AP) solution in both upper and lower parts of stems, suggesting that polar IAA transport might be only $19 \%$ of the amount of IAA in stems. Concentration of ABA was high in the pericarp, axis and the locule tissue in the fruits. Warda ${ }^{110}$ reported large amount of $\mathrm{GA}_{3}$-like substances and ABA in the developing seeds of cucumber (Cucumis sativa). Munoz et al., ${ }^{111}$ studied the role of endogenous CKs on reserve mobilization in cotyledons of Cicerarietinum. He suggested that CKs are concerned with the metabolism of carbohydrates and proteins. Dewar et al., ${ }^{112}$ used HPLC to assay the amount of CKs-Zeatin (Z), Z. reboside (ZR) and isopentenyladenine (IPA) and combined amounts of $\mathrm{GA}_{1}, \mathrm{GA}_{3}$, IAA and ABA during germination in sorghum. He reported higher concentration endogenous $\mathrm{ABA}$ in the embryo prior to germination. No study has been conducted on the endogenous hormones in bamboo seeds except for the only work by Richa et al., ${ }^{43}$ who studied the endogenous levels of IAA and ABA in five bamboo species viz. Bambusabambos, Dendrocalamusmembranaceus, Gigantochloaalbociliata, Thyrsotachyssiamensis and Dendrocalamusstrictus. These authors reported an increase in the levels of free ABA in all the five bamboo species, with maximum amount in Dendrocalamusstrictus and minimum in Bambusabambos, after 12 months of storage. A significant decline in the endogenous levels of IAA was also observed in D. strictus, which also showed maximum decline in viability. ${ }^{113,114}$

\section{Conclusion}

From the above discussion, it can be concluded that bamboo seeds undergo age-induced biochemical and physiological changes, similar to that of cereals. Age-induced deterioration brings about membrane damage, causes leakage of reserve food material and enzyme degradation. Change in the optimum levels of plant hormones was also discussed. Seed viability could be retained for a greater period by storing the seeds under controlled conditions. The decline in vigour and viability of seeds is recoverable to some extent by the appropriate application of various seed invigoration treatments.

\section{Acknowledgements}

None.

\section{Conflict of interest}

The author declares that there is no conflict of interest.

\section{References}

1. Bystriakova N, Kapos V, Lysenko I. Bamboo Biodiversity-Africa, Madagascar and the Americas. UK: UNEP-WCMC/INBAR, A Bandson Production; 2004.

2. INBAR. The plant with thousand faces. 1997;5:13.

3. Banik RL. Studies on seed germination, seedling growth and nursery management of Melocannabaccifera (Roxb.) Kurz. In: Proceedings $4^{\text {th }}$ International Bamboo Workshop on Bamboo in Asia and the Pacific. Italy: Food and Agriculture Organization of the United Nations; 1994. $113-119 \mathrm{p}$

4. Ravikumar R, Ananthakrishnan G, Ganapathi A. Viability of bamboo (Dendrocalamusstrictus Nees) seeds under four different storage conditions. Seed Res. 1998;26:43-46.

5. Ravikumar R, Ananthakrishnan G, Ganapathi A. et al. Biochemical changes induced by accelerated ageing in Bambusabamboos seeds. Biologia Plantarum. 1997;40(3):459-464

6. Koshy KC, Harikumar D. Reproductive biology of Ochlandra scriptoria, an endemic reed bamboo of the Western Ghats, India. Bamboo Science and Culture. 2001;15:1-7.

7. Rawat MMS, RC Thapliyal. Storage behaviour of bamboo (Dendrocalamus membranaceus) seeds. Seed Science and Technology. 2003;31(2):397-340.

8. Barens RF. Foreword. In: Physiology of Seed Deterioration. McDonald, et al. editors. USA: Crop Sci Soc of America Special Publication; 1986. $11 \mathrm{p}$.

9. Roberts EH. Predicting the storage life of seed. Seed Sci Technol. 1973;1:499-514.

10. Ellis RH, Hong TD, Roberts EH, et al. Low-moisture content limit to relations between seed longevity and moisture. Annals of Botany. 1990;65(5):493-504.

11. Wilson DO, Mc Donald MB. The lipid peroxidation model of seed aging. Seed Sci Technol. 1986;14:269-300.

12. McDonald MB. Seed deterioration: physiology, repair and assessment. Seed Science and Technology. 1999;27(1):177-237.

13. Matsuda H, Hirayama O. Changes of lipid components and lipolyticacylhydrolase activities in rice grains during their storage. Nippon Nōgeikagaku Kaishi. 1973;47(6):279-384. 
14. Priestley DA, Leopold AC. Lipid changes during natural ageing of soybean seeds. Physiologia Plantarum. 1983;59(3):467-470.

15. Petruzzelli L, G Taranto. Phospholipid changes in wheat embryos aged under different storage conditions. Journal of Experimental Botany. 1984;35(4):517-520.

16. Sun WQ, Leopold AC. The glassy state and accelerated aging of soybeans Physiologia Plantarum. 1993;89(4):767-774.

17. Williams RJ, Leopold AC. The glassy state in corn embryos. Plant Physiol. 1989;89(3):977-981.

18. Sun WQ, Leopold AC. Cytoplasmic vitrification and survival of anhydrobiotic organisms. Comparative Biochemistry and Physiology. 1997;117(3):327-333.

19. Leopold AC, Sun WQ, Bernal Lugo I. The glassy states in seeds: Analysis and function. Seed Science Research. 1994;4(3):267-274.

20. Sun WQ, Koh DCY, Ong CM. Correlation of modified water sorption properties with the decline of storage stability of osmotically-primed seeds of Vigna radiata (L.) Wilczek. Seed Science Research. 1998;7(4):391397.

21. Bewley JD, M Black. Cellular events during germination and seedling growth. Seeds. 1994;147-197.

22. Taiz L, E Zeiger. Plant Physiology. 3rd ed. Panima Publishing Corporation. 2002;91(6):750-751.

23. Bewley JD. Seed germination and dormancy. The Plant Cell. 1997;9:1055-1066.

24. Bewley JD, M Black. Physiology and Biochemistry of Seeds. New York: Springer-Verlag; 1983.

25. Come D, Corbineau F. Some aspects of metabolic regulation of seed germination and dormancy. In: editors. Recent advances in the development and germination of seeds; 1989. 165-179 p.

26. Job C, A Kersulec, L Ravasio, et al. The solubilization of the basic subunit of sugarbeet seed 11-S globulin during priming and early germination. Seed Science Research. 1997;7(3):225-243.

27. Gallardo K, C Job, SPC Groot, et al. Proteomic analysis of Arabidopsis seed germination and priming. Plant Physiol. 2001;126(2):835-848.

28. Filner P, JE Varner. A test for de novo synthesis of enzymes: density labeling with $\mathrm{H}_{2} \mathrm{O}_{18}$ of barley $\alpha$-amylase induced by gibberellic acid. Proc Natl Acad Sci USA. 1967;58(4):1520-1526.

29. Bewley JD, M Black. Imbibition, germination and growth. In: Physiology and Biochemistry of Seeds. Vol I. Development Germination and Growth New York: Springer-Verlag; 1978.

30. Nandi S, G Das, SD Sen-Mandi. $\beta$-amylase activity as an index for germination potential in rice. Annals of Botany. 1995;75(5):463-467.

31. De Miguel L, MJ Burgin, JJ Casal et al. Antagonistic action of low-fluence and high-irradiance models of response to photochrome on germination and $\beta$-mannanase activity of Datura ferox seeds. Journal of Experimental Botany. 2000;51:1127-1133.

32. Feurtado JA, M Banik, JD Bewley. The cloning and characterization of $\alpha$-galactosidase present during and following germination of tomato (Lycopersicon esculentum Mill.) seed. J Exp Bot. 2001;52(359):12391249.

33. Mo B, JD Bewley. $\beta$-Mannosidase (EC 3.2.1.25) activity during and following germination of tomato (Lycopersicon esculentum Mill.) seeds. Purification, cloning and characterization. Planta. 2002;215(1):141-152.
34. Adebisi MA, Ola JA, Akintobi DAC. Et al. Storage life of sesame (Sesamum indicum L.) seeds under humid tropical conditions. Seed Science and Technology. 2008;36(2):379-387.

35. Muntz k, MA Belozersky, YE Dunaevsky, et al. Stored proteinases and the initiation of storage protein mobilization in seeds during germination and seedling growth. Journal of Experimental Botany. 2001;52(362):17411752 .

36. Asghar R, DA Demason. Developmental changes in the cotyledons of Lupinusluteus L. during and after germination. American Journal of Botony. 1990;77(10):1342-1353.

37. Dias P, KA Wilson, Tan-Wilson AL. Immuno cyto chemical analysis of proteolysis in germinating soyabean. Phytochemistry. 1993;33:961-968.

38. Walters C, Wheeler LM, Grotenhuis JM. Longevity of seeds stored in a gene bank: species characteristics. Seed Science Research. 2005;15(1):1120 .

39. Ching TM. Adenosine Triphosphate and seed vigour. In: The Physiology and Biochemistry of Seed Development, Dormancy and Germination, AA Khan, editor. Amsterdam: Elsevier Biomedical Press; 1982. 487-506 p.

40. Cheah KSE, Osborne DJ. DNA lesions occur with loss of viability in embryos of ageing rye seed. Nature. 1978;272(5654):593-599.

41. Bewley JD, M Black. Physiology and Biochemistry of Seeds in Relation to Germination. New York: Viability, Dormancy, and Environmental Control; 1982.378 p

42. Richa ML, Sharma, Vikas Kumar. Viability and enzyme activity of ageing seeds of bamboo (Dendrocalamusstrictus (Roxb.) Nees) in relation to exogenous plant growth regulators. Current Science. 2010;99(11):1590 1593.

43. Richa, ML Sharma, Neeru Bala. Studies on endogenous levels of plant growth hormones in relation to seed viability in some bamboo seeds. Indian J Plant Physiol. 2006;11(4):358-363.

44. VanBilsen DGJL, FA Hoekstra, LM Crowe et al. Altered phase behaviour in membranes of aging dry pollen may cause imbibitional leakage. Plant Physiology. 1994;104(4):1193-1193.

45. Smith MT, Berjak P. Deteriorative changes associated with the loss of viability of stored desiccation-tolerant and desiccation-sensitive seeds. In: Kigel J, et al. editors. Seed development and germination. New York: Marcel Dekker, Inc; 1995. 701-746 p.

46. Walters C. Understanding the mechanisms and kinetics of seed ageing Seed Science Research. 1998;8(2):223-244.

47. Horbowicz M, Obendorf RL. Seed desiccation tolerance and storability: dependence on flatulence producing oligosaccharides and cyclitols review and survey. Seed Science Research. 1994;4(4):385-405.

48. Seethalakshmi KK. Collection and storage of bamboo seeds. BIC-India Bulletin. 1991;1(1):1.

49. Warrier RR, Sivakumar V, Ananda lakshmi R, et al. Improving storability of Bambusaarundinacea (Retz.) Wild seeds. Journal of Bamboo and Rattan. 2004;3:375-382.

50. Priestley DA, Leopold AC. Absence of lipid oxidation during accelerated aging of soybean seeds. Plant Physiol. 1979;63(4):726-729.

51. Senaratna T, JF Gusse, BD McKersie. Age-induced changes in cellular membranes of imbibed soybean seed axes. Physiol Plant. 1988;73(1):8590

52. Ferguson JM, DM Tekrony, DE Egli. Changes During Early Soybean Seed and Axes Deterioration: II. Lipids. Crop Science. 1988;30(1):179182. 
53. Parrish DJ, Leopold AC. On the mechanism of ageing in soybean seeds Plant Physiol. 1978;61(3):365-368.

54. Pandey DK. Liquid preservatives to improve longevity of tomato (Lycopersicum esculentum L.) seeds. Scientia Horticulturae. 1992;62(12):57-62.

55. Hampton JG, TeKrony DM. Conductivity test. Handbook of Vigour Test Methods. 3rd ed. 1995;22-34.

56. Dias DCFS, J Marcos-Filho, Carmello QAC. Potassium leakage test for the evaluation of vigor in soybean seeds. Seed Sci Technol. 1996;25:7-18.

57. Rehman S, Harris PJC, Bourne WF. Effect of artificial ageing on the germination, ion leakage and salinity tolerance of Acacia tortilis and A. coriacea seeds. International Seed Testing Association Ista. 1999;27(1):141-149

58. Simon E. Phospholipid and plant membrane permeability. New Phytol. 1974;73(3):377-420.

59. Machado Neto NB, CC Custodio, M Takaki. Evaluation of naturally and artificially aged seeds of Phaseolus vulgaris L. Seed Science and Technology. 2001;29(1):137-149.

60. Dell Aquila A, Margiotta B. DNA synthesis and mitotic activity in germinating wheat seeds aged under various conditions. Environmental and Experimental Botany. 1986;26:175-184.

61. Reuzeau C, G Cavalie. Activities of free radical processing Enzymes in dry sunflower seeds. New Phytologist. 1995;130(1):59-66.

62. Pukacka S. Changes in membrane lipid components and antioxidantlevels during natural ageing of seeds of Acer platanoides. Physiologia Plantarum. 1991;82(2):306-310.

63. Lehner A, Mamadou N, Poels P, et al. Changes in soluble carbohydrates, lipid peroxidation and antioxidant enzyme activities in the embryo during ageing in wheat grains. Journal of Cereal Science. 2008;47(3):555-565.

64. Afzal I, Ashraf S, Qasim M, et al. Does halopriming improve germination and seedling vigour in marigold (Tagetes spp.). Seed Science and Technology. 2009;37(2):436-445.

65. Singh BK, Sharma SR, Singh B. Antioxidant enzymes in cabbage: Variability and inheritance of superoxide dismutase, peroxidase and catalase. Scientia Horticulturae. 2010;124(1):9-13.

66. Basavarajappa BS, HS Shetty, HS Prakash. Membrane deterioration and other biochemical changes associated with accelerated ageing of maize seeds. Seed Science and Technology. 1991;19(2):279-286.

67. Das G, S Sen-Mandi. Scutellar amylase activity in naturally aged and accelerated aged wheat seeds. Annals of Botany. 1992;69(6):495-501.

68. Saxena OP, T Pakeeraiah, P Lakshmi. Studies on accelerated ageing in seasamum. Indian J Plant Physiol. 1985;27:35-42.

69. Kannababu, TV Karivaratharaju. Effect of seed ageing on malate dehydrogenase and succinate dehydrogenase activity in seedling of sunflower. Indian Journal of Plant Physiology. 2000;5(4):397-399.

70. De Tullio MC, Arrigoni O. The ascorbic acid system in seeds: to protect and to serve. Seed Science Research. 2003;13(4):249-260.

71. Pukacka S, Ratajczak E. Age-related biochemical changes during storage of beech (Fagus sylvatica L.) seeds. Seed Science Research. 2007; 17(1):45-53.

72. Prescott AG, John P. Dioxygenases: molecular structure and role in plan metabolism. Annu Rev Plant Physiol Plant Mol Biol. 1996;47:245-271.

73. Arrigoni O, De Tullio MC. The role of ascorbic acid in cell metabolism: between gene-directed functions and unpredictable chemical reactions. Journal of Plant Physiology. 2000;157(5):481-488.
74. Arrigoni O, De Tullio MC. Ascorbic acid: much more than just an antioxidant. Biochim Biophys Acta. 2002;1569(1-3):1-9.

75. Pastori GM, Kiddle G, Antoniw J, et al. Leaf vitamin-C contents modulate plant defense transcripts and regulate genes that control development through hormone signaling. Plant Cell. 2003;15(4):939-951.

76. Klapheck S, Zimmer I, Cosse H. Scavenging of hydrogen peroxide in the endosperm of Ricinuscommunis by ascorbate peroxidase. Plant and Cell Physiology. 1990;31(7):1005-1013.

77. De Gara L, de Pinto MC, Moliterni VMC, et al. Redox regulation and storage processes during maturation in kernels of Triticum durum. J Exp Bot. 2003;54(381):249-258.

78. Arrigoni O, De Gara L, Tommasi F et al. Changes in the ascorbate system during seed development in Viciafaba L. Plant Physiol. 1992;99(1):235238.

79. Finnie C, Melchior S, Roepstorff $\mathrm{P}$, et al. Proteome analysis of grain filling and seed maturation in barley. Plant Physiology. 2002;129:1308-1319.

80. Walters C, Wheeler L, Stanwood PC. Longevity of cryogenically stored seeds. Cryobiology. 2004;48(3):229-244.

81. Rajjou L, Debeaujon I. Seed longevity: Survival and maintenance of high germination ability of dry seeds. C R Biol. 2008;331:796-805.

82. McKersie BD, Senaratna T, Walker MA, et al. Deterioration of membranes during aging in plants: evidence for free radical mediation. In: LD Nooden, editors. Senescence and Aging in Plants. New York: Academic Press Inc; 1988. 441-464 p.

83. Chan HWS. The mechanism of auto oxidation. In HWS Chan, editor Auto oxidation of Unsaturated Lipids. New York: Academic Press; 1987. $1-16 \mathrm{p}$.

84. Bailly C. Active oxygen species and antioxidants in seed biology. Seed Science Research. 2004;14:93-107.

85. Ratajczak E, Pukacka S. Decrease in beech (Fagus sylvatica) seed viability caused by temperature and humidity conditions as related to membrane damage and lipid composition. Acta Physiologiae Plantarum. 2005;27(1):3-12.

86. Liu MS, Chang CY, Lin TP. Comparison of phospholipids and their fatty acids in recalcitrant and orthodox seeds. Seed Science and Technology. 2006;34(2):443-452.

87. Bedi S, Kaur R, Sital JS, et al. Artificial ageing of Brassica seeds of different maturity levels. Seed Science and Technology. 2006;34(2):287296.

88. Chabot JF, AC Leopold. Ultra structural changes of membranes with hydration in soybean seeds. American Journal of Botany. 1982;69(4):623633.

89. Chabot JF, AC Leopold. Ultra structural aspects of chilling injury in soybean seed radicle. American Journal of Botany. 1985;72(7):1120 1126.

90. Yaklich RW, B Vinyard, M Camp et al. Analysis of seed protein and oil from soybean northern and southern region uniform tests. Crop Sci. 2001;42(5):1504-1515

91. Hawkins CL, Davies MJ. Generation and propagation of radical reactions on proteins. Biochim Biophys Acta. 2001;1504(2-3):196-219.

92. Stadtman ER. Protein oxidation and aging. Free Radic Res 1992;40(12):1250-1258.

93. Job C, Rajjou L, Lovigny Y, et al. Patterns of protein oxidation in Arabidopsis seeds and during germination. Plant Physiology. 2005;138:790-802 
94. Khan MM, Iqbal MJ, Abbas M. Loss of viability correlates with membrane damage in aged turnip (Brassica rapa) seeds. Seed Science and Technology. 2005;33(2):517-520.

95. Kaewnaree P, Vichitphan S, Klanrit P, et al. Electrolyte leakage and fatty acid changing associated with seed germination in accelerated aging sweet pepper seeds. Journal of Biotechnology. 2008;136:147-169.

96. Clifford PE, Offler CE, Patrick JW. Growth regulators have rapid effects on photosynthate unloading from seed coats of Phaseolus Vulgaris. L. Plant Physiol. 1986;80(3):637-637.

97. Mark L. Brenner, Nordine Cheikh. The role of hormones in photosynthate partitioning and seed filling. Plant Hormones. 1987;649-670 p.

98. Patrick JW. Assimilate partitioning in relation to crop productivity. Hort science. 1988;23:33-40.

99. Kucera B, Cohn MA, Leubner-Metzger G. Plant hormone interactions during seed dormancy release and germination. Seed Science Research. 2005;15(4):281-307.

100. Briggs DE. Hormones and carbohydrates metabolism in germinating cereal grains. In: Biosynthesis and its control in Plants. Milborrow BV, editors. London: Academic Press; 1973. 219-277 p.

101. Karssen CM, S Zagorski, J Kepczynski, et al. Key role for endogenous gibberellins in the control of seed germination. Annals of Botony. 1989;63(1):71-80.

102. Mrva K, DJ Mares. Regulation of high pI alpha-amylase synthesis in wheat aleurone by a gene(s) located on chromosome 6B. Euphytica. 1999;109(1):17-23.

103. Huarte HR, Benech-Arnold, RL. Hormonal nature of seed responses to fluctuating temperatures in Cynaracardunculus (L.). Seed Science Research. 2010;20(1):39-45.

104. Bethke PC, SJ Swanson, S Hillmer, et al. From storage compartment to lytic organelle: the metamorphosis of the aleurone protein storage vacuole. Annals of Botany. 1998;82(4):399-412.
105. Haberlandt G. Physiologische Pflanzenanatomie. 1st ed. W Engelman. Leipzig: Plant physiology; 1884.

106. Fath A, V Belligni, P Bethke, et al. Signaling in the cereal aleurone: Hormones, reactive oxygen species and cell death. New Phytoogistl. 2001;151(1):99-107.

107. Wang H, Qi Q, Schorr P, et al. ICK1, A cyclin-dependent protein kinase inhibitor from Arabidopsis thaliana interacts with both Cdc2a and CycD3, and its expression is induced by abscisic acid. Plant J. 1998;15(4):501510.

108. Kong L, SM Attree, LCFowke. Changes of endogenous hormone levels in developing seeds, Zygotic embryo and megagametophytes in Picea glauca. Physiol Plant. 1997;101(1):23-30.

109. Kojima K. Phytohormones in shoots and fruits of tomato; apoplast solution and seedless fruit. Japan Agricultural Research Qu. 2005;39(2):77-81.

110. Warda DA, MacMillanb J, Gonga F, et al. Gibberellin 3-oxidases in developing embryos of the southern wild cucumber, Marah macrocarpus. Phytochemistry. 2010;71(17-18):2010-2018.

111. Munoz JL, L Martin, G Nicolas et al. Influence of Endogenous Cytokinins on Reserve Mobilization in Cotyledons of Cicerarientinum L. Plant Physiol. 1990;93(3):1011-1016.

112. Dewar J, Taylor JRN, Berjak P. Changes in selected plant growth regulators during germination in sorghum. Seed Science Research. 1998;8(1):1-8.

113. Richa ML Sharma, P Kaur. Effect of exogenous application of some plant growth regulators on enzyme activity with ageing of bamboo seeds. JPAS. 2000;2(1):35-42.

114. Roberts EH. Seed deterioration and loss of viability. JR Thomson, editor. Advances in Research and Technology of Seeds. 1979;4:25-42. 